\title{
Оптические свойства поверхности кремния после плазменных обработок
}

\author{
Л.Н. Сафронов, В.А.Антонов, Э.Д. Жанаев, В.П. Попов, Е.В. Спесивцев \\ Институт физики полупроводников им. А.В. Ржанова СО РАН \\ Новосибирск 630090, пр. Ак. Лаврентьева, 13
}

Тел.: +7(383)333-25-37, эл. почта: popov@isp.nsc.ru

DOI 10.34077/RCSP2019-31

Плазменные обработки широко используются для пассивации и снижения скорости поверхностной рекомбинации в солнечных элементах (СЭ) и фотоприемниках. Кроме того, условия обработки поверхности кремния определяют свойства ОПЗ и слоев окисла на границе сращивания пластин n- и р-типа, соединяемых путем бондинга для многопереходных СЭ. В работе исследовано влияние газового состава плазмы с диэлектрическим барьером, пассивирующей поверхность кремния при атмосферном давлении (DBD) на оборудовании SUSS MicroTec.

Анализ соединений, образующихся на поверхности кремня, проводился методом многократного нарушенного полного внутреннего отражения (МНПВО). Из пластин безкислородного кремния с двухсторонней полировкой изготавливались образцы размером 40 х 20 мм. Короткие торцы шлифовались под углом $45^{\circ}$ и полировались так, что получалась трапеция. ИК излучение вводилось/выводилось через короткие полированные грани призмы и, таким образом на спектрометре IFS 66 регистрировался спектр пропускания призмы после приблизительно 100 отражений от поверхности. Исходно регистрировался спектр пропускания призм с гидрофобной поверхностью после химической обработки. Этот спектр поглощения вычитался из спектра поглощения призмы, обработанной в DBD плазме.

На рисунке 1 приведены такие разностные спектры поглощения призм, обработанных в азотной плазме без водорода и с добавление водорода. Отметим, что после обработки поверхности в плазме любого состава поверхность кремния становится гидрофильной, что проявляется в виде широкой составной полосы вблизи $3500 \mathrm{~cm}^{-1}$. Как видно из рисунка при обработке в плазме исчезают первоначально присутствовавшие $\mathrm{Si}-\mathrm{H}$ и $\mathrm{C}-\mathrm{H}$ связи, однако на гидрофильной поверхности формируется пленка $\mathrm{SiO}_{2}$ (LO и ТО фононы) с различными свойствами.

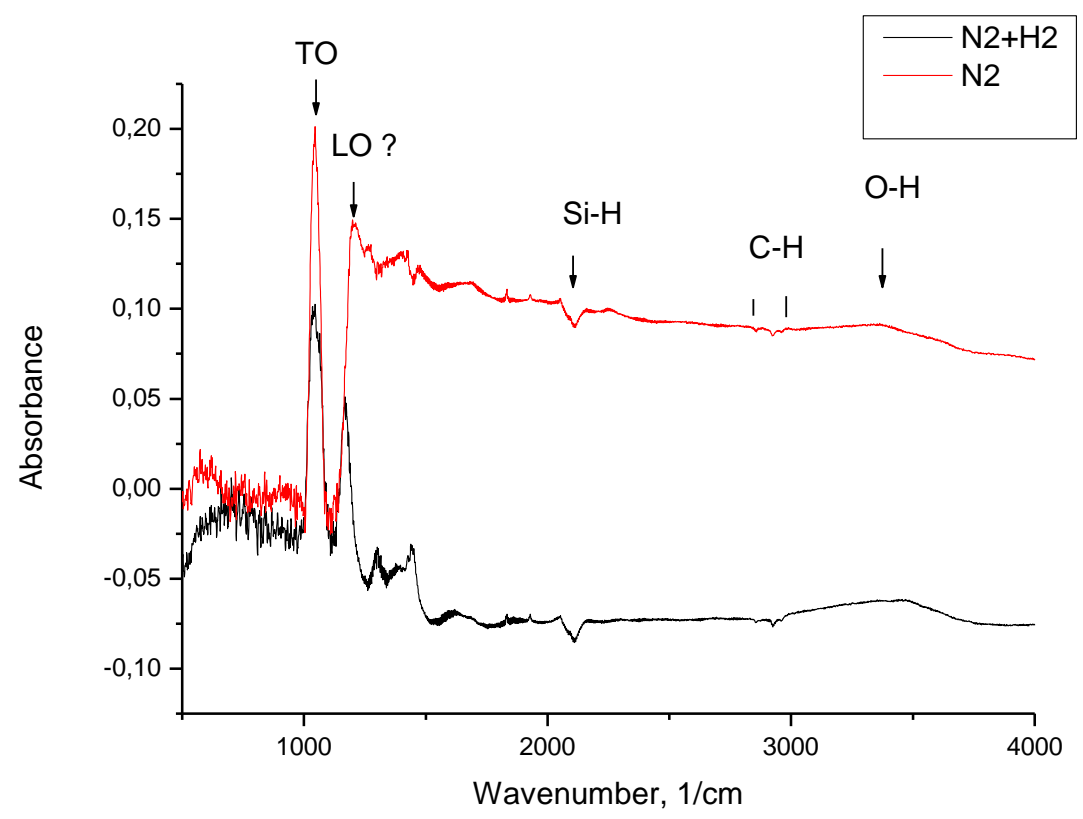

Рисунок 1. Разностные спектры поглощения призмами МНПВО, обработанными в азотной DBD плазме. 